\title{
The Road
}





\section{The Road}

\section{Indian Tribes}

\section{and Political Liberty}

Russel Lawrence Barsh

and James Youngblood Henderson

University of California Press

BERKELEY - LOS ANGELES - LONDON 
University of California Press

Berkeley and Los Angeles, California

University of California Press, Ltd.

London, England

(C) 1980 by

The Regents of the University of California

First paperback printing 1982

ISBN 0-520-04636-6

Library of Congress Catalog Card Number: 77-91777

Printed in the United States of America

123456789

An earlier version of part three of this book previously appeared in R.L. Barsh, "The Omen: Three Affiliated Tribes v. Moe and the Future of Tribal Self-Government," 5 American Indian Law Review I (1977). 
Dedicated to and in honor of

Elizabeth Tracy Barsh

and

Marie Anne Battiste, Jaime Youngmedicine, and Mariah Sundaylaces 
